Available online on 15.03.2021 at http://ujpr.org
Universal Journal of Pharmaceutical Research
An International Peer Reviewed Journal
Open access to Pharmaceutical research

\title{
HISTOLOGIC AND RADIOGRAPHIC STUDY OF PATHOLOGIC CHANGE IN COMPLETE IMPACTED THIRD MOLARS DENTAL FOLLICLES Shafiqa Mohammed Haidra Masdoose ${ }^{1}$, Akram Thabet Nasher ${ }^{1}{ }^{10}$, Monya A. El-Zine ${ }^{2}$, Ameen Abdullah Yahya Al-Akwa ${ }^{3}{ }^{\mathbb{D}}$, Hassan Abdulwahab Al-Shamahy ${ }^{4}$, Mohammed A Al-labani ${ }^{3}$ (D) \\ ${ }^{1}$ Department of Maxillo-Facial, Faculty of Dentistry, Sana' a University, Republic of Yemen. ${ }^{2}$ Departement of Histopathology, Faculty of Medicine and Health Sciences, Sana'a University, Republic of Yemen. ${ }^{3}$ Orthodontics, Pedodontics and Prevention Department Faculty of Dentistry, Sana'a University, Yemen. ${ }^{4}$ Departement of Basic Sciences, Faculty of Dentistry, Sana' a University, Republic of Yemen.
}

\section{ABSTRACT}

Background: Prophylactic extraction of the asymptomatic impacted third molar is routinely practiced in Europe and the United States. The justification for prophylactic extraction includes the need to reduce the risk of pathologic changes such as cysts and tumors.

Objectives: This study aimed to study the histological and radiological changes in the tooth follicles of upper and lower complete impacted $3^{\text {rd }}$ molars -which appeared radiologically normal.

Material and method: A prospective study included fifty patients aged 20 years and above who were referred to the Oral Surgery Clinic, Faculty of Dentistry, University of Sana'a. Patients had follicular space between $(2.5 \mathrm{~mm}-3 \mathrm{~mm})$ as measured by the panoramic X-ray. These teeth were removed surgically and the follicle was sent for histopathological examination.

Results: Most histopathological changes were in dental follicles with a size of $<2.5 \mathrm{~mm}(86 \%)$, and only $14 \%$ with $2.5 \mathrm{~mm}-3$ $\mathrm{mm}$. There was statistical significance between the smallest size of dental follicles with the incidence of pathological histological changes. Of the 50 follicular patients, $28 \%$ showed $\mathrm{HC}$, nine (64\%) had ameloblastoma, four (29\%) had a dentigerous cyst, and only one case $(7 \%)$ had a multicalcified focus with islands of odontogenic epithelium. While $72 \%$ of the samples had normal follicles and non-specific chronic inflammatory cells. There is an association between female sex and pathological histological changes (12 females: 2 males, $p=0.008)$, age group $21-25$ years $(93 \% \mathrm{HC})$, with mandibles $(65 \% \mathrm{HC})$. Regarding angle and histopathological changes, 36\% were vertical, $29 \%$ mesioangular, $14.2 \%$ horizontal and destioangular, and $7.1 \%$ buccoangular.

Conclusion: High incidence of $\mathrm{HC}$ occurred in patients with DF, and it was associated with smaller dental follicle size, most HC was ameloblastoma, followed by dentigerous cyst, while $72 \%$ of samples had normal follicles and non-specific chronic inflammatory cells. There is a correlation between female gender, younger age group, and jaw position with HC. Prophylactic extraction of the asymptomatic impacted third molar should be routinely practiced in Yemen, to reduce the risk of pathological changes, especially in females and younger age groups.

Keywords: Dental follicle (DF), histopathological changes (HC), Impacted Third Molars, Oral pathology, Radiographic width, Sana'a, Yemen.

Article Info: Received 4 January 2021; Revised 3 February; Accepted 28 February, Available online 15 March 2021

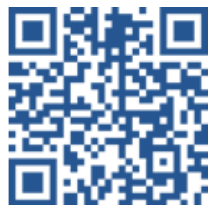
Cite this article-

Masdoose SMH, Nasher AT, El-Zine MA, Al-Akwa AAY, Al-Shamahy HA, Al-labani MA. Histologic and radiographic study of pathologic change in complete impacted third molars dental follicles. Universal Journal of Pharmaceutical Research 2021; 6(1):43-48.

DOI: https://doi.org/10.22270/ujpr.v6i1.539

Address for Correspondence:

Prof. Hassan A. Al-Shamahy, Faculty of Dentistry, Sana'a University, P.O. Box 775 Sana'a, Yemen. Tel- +967-770299847; Email:shmahe@yemen.net.ye

\section{INTRODUCTION}

Dental follicle or the primitive dental sac, which initiates from odontogenic ectomesenchyme, is part of the tooth germ and is physiologically concerned in the formation of cementum, periodontal ligament, and alveolar bone. This fibrous connective tissue typically includes odontogenic cell rests, which could be the source of any pathology similar to ameloblastoma, ameloblastic fibroma etc., radiographically it becomes visible as thin pericoronal radiolucency, believed normal by some authors when within $3 \mathrm{~mm}$ of thickness and by others when it is within $2.5 \mathrm{~mm}$ of thickness ${ }^{1,2}$. Reports in the literature discussed the prevalence of 
various cyst and tumour development associated with the asymptomatic follicle of impacted tooth ${ }^{3}$. Dental follicle may illustrate various histopathological changes during tooth development which may sometimes cause the development of odontogenic tumours and cysts. Foci of calcification are seen as an ordinary finding in the stroma of dental follicles ${ }^{3}$. The hard tissue formation has been considered as a subclassification in the WHO classification of odontogenic tumours; however, in earlier studies on dental follicle, this parameter has not been much explored. Epithelialmesenchymal interactions play an important role in odontogenesis and its associated pathologies and therefore in the studies of dental follicle, along with epithelial component emphasis should be laid on mesenchyme as well ${ }^{2}$.

To our knowledge and according to the archive of the Library of the National Information Center in Yemen, which contains database of more than 13,000 scientific papers and few of them were in diseases and disorders of teeth ${ }^{4-13}$, there is no study in Yemen that was conducted to investigate the histological and radiological changes in the complete impacted $3^{\text {rd }}$ molars dental follicles. Thus this is the first study in this important topic. This study was carried out to assess the histological and radiological changes in dental follicles of the upper and lower complete impacted $3^{\text {rd }}$ molars- which appeared radiographically normal - among Yemeni people, Sana'a city. The study determined the incidence of histolopathological changes in soft tissues surrounding impacted third molar teeth (pericoronal tissues) among patients 20 years of age and above, and also determined the need for routine removal of complete impacted third molars under the prophylactic indication, the types of $\mathrm{HC}$, size of dental follicle, and others factors that associated with HC in soft tissues in dental follicles as gender, age of the patients, site (Mandible\Maxilla), side (right $\backslash$ left), and angulation.

\section{SUBJECTS AND METHODS}

A prospective study was conducted to determine the incidence of histological and radiological changes in soft tissue (dental follicles) around the complete impacted $3^{\text {rd }}$ molars (which appeared radiographically normal and no clinical evidence of changes). The study population included patients who had been referred to the clinic of Oral Surgery, Faculty of Dentistry, Sana'a University for extraction of complete impacted $3^{\text {rd }}$ molars in Sana'a City between March 2018 to March 2019.

\section{Inclusion criteria}

a. Age of patient 20 years old and above.

b. Complete impacted $3^{\text {rd }}$ molars

c. Dental follicle space between $(<2.5 \mathrm{~mm}-\leq$ $3 \mathrm{~mm})$.

d. d) No pathological evidence in panoramic film. e) No abnormal soft tissue in mucosa which covering the tooth (impacted $3^{\text {rd }}$ molars).

\section{Exclusion criteria}

a. Partially impacted $3^{\text {rd }}$ molars.

b. Medically compromised patients. c. Dental follicles were ruptured and lost through an aggressive work during extraction of the impacted tooth.

d. Associated pathology in panoramic film of the impacted $3^{\text {rd }}$ molars.

e. Previous operation or fracture in mandible at the site of $3^{\text {rd }}$ molars.

\section{Clinical works and Data collection}

All patients had undergone a clinical assessment and all information was collected in a data collection sheet (case sheet), which was designed to have a methodological recording. All the panoramic images were done in (Al-Waleed $\mathrm{x}$-ray). The model of machine is Pax i 3D Green $15 \times 15$ (PHT - 60 CFO), company VATECH, made in South Korea. After panoramic X-ray was taken to the patients, all impacted $3^{\text {rd }}$ molars were classified based on Winter's classification. On the image of impacted $3^{\text {rd }}$ molars two perpendicular lines (AA and $\mathrm{BB}$ ) were drawn, one of the line passed through the center of the crown and the other line passed through the long axis of the tooth. From the point where the two lines intersected, a ruler in digital program was moved to the widest part of the follicular space and measurement of the size of dental follicle of the complete impacted $3^{\text {rd }}$ molars were obtained. Impacted $3^{\text {rd }}$ molars patients who had follicular space $(<2.5 \mathrm{~mm})$ and $(2.5 \mathrm{~mm}-\leq 3 \mathrm{~mm})$ were included in the study.

\section{Reliability of measurement}

The observer repeated the measurement of the widest space of the follicular space with the same means of measurement mentioned above. A comparison was made between the $1^{\text {st }}, 2^{\text {nd }}, 3^{\text {rd }}$ measurements to determine the reliability ratio between the three measurements, the results showed that Cronbach 's Alpha coefficient was (0.910) which means that all readings were reliable.

\section{Surgical procedure}

Surgical site of impacted third molars region was irrigated with normal saline and prepared for the surgical procedure. Infiltration was placed in addition to Inferior Alveolar Nerve Block (I.A.N. B). A scalpel with number 15 blade was used to make incision for the creation of a flap (Triangular flap). A full mucoperiosteal flap was elevated by using a periosteal elevator. Then a straight hand- piece with adequate speed and torque was used to remove bone from occlusal aspect of tooth with copious normal saline irrigation. Bone guttering was done up to cervical line, buccal and distal aspect, buccal cortical plate was removed minimally. In horizontal impaction, crown was sectioned from the roots in vertical plane. In vertically impacted teeth, the distal aspect of the crown was sectioned and removed first. In the case of distoangular impaction, it was sectioned to the distal portion of the crown or complete crown in horizontal plate and then removed. After removal of impacted teeth a proper and adequate debridment was done. Round bur and bone file were used to smoothen any sharper bony edges. The follicle was enucleated from the socket by using hemostat and periapical curette and then cleaned with normal saline and closure of the flap was done with 3-0 black silk interrupted sutures. 
Follicular tissue was cleaned with normal saline and sent for histopathology in $10 \%$ formalin.

Histopathological procedure

The dental follicle specimens were processed and sections were obtained from the blocks embedded in paraffin. This was done using a rotarymicrotome and stained using Hematoxylin and Eosin stains and montage on slides and viewed under microscope by histopathologist.

Statistical analysis

Data were reported using appropriate descriptive statistics (including frequency, mean, standard deviation, and p-value). All statistical analyzes of the data were performed using the Statistical Package for Social Sciences (SPSS) version 24 and Excel 2007. They were recorded after data were collected and entered into SPSS for analysis. The Chi-square test was used to investigate the significant differences in the incidence of pathological changes in the tooth follicles of the affected third molars with size ranging from $(<2.5 \mathrm{~mm})$ to $(2.5 \mathrm{~mm}-3 \mathrm{~mm})$, gender and location, side and size of the tooth follicle, and 2007 excels in the other variables (age, places, causes of extraction).

Ethical Approval

Ethical approval was obtained from the Medical Research and Ethics Committee of the Faculty of Dentistry, Sana'a University. All data, including patient identification were kept confidential.

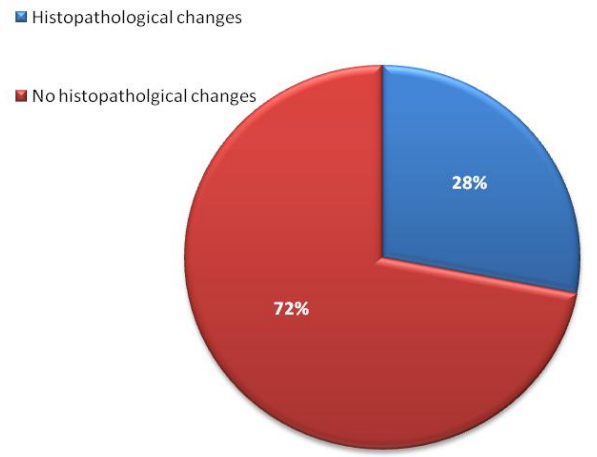

Figure 1: The distribution of histopathological changes in dental follicles of the complete impacted $3^{\text {rd }}$ molars.

\section{RESULTS}

Distribution of histopathological changes in dental follicles: Of the fifty dental follicles from complete impacted $3^{\text {rd }}$ molars that were evaluated, fourteen $(28 \%)$ showed pathological changes and $36(72 \%)$ did not show any histological changes and there was a significant difference for the occurrence of pathological change $(\mathrm{p}=0.002)$ (Figure 1).

Types of histopatholgical changes in dental follicles of the complete impacted $3^{\text {rd }}$ molars: According to histopathology results, nine $(64 \%)$ were ameloblastoma, four (29\%) were dentigerous cyst and only one case $(7 \%)$ was multicalicified focus with islands of odontogenic epithelium, (Figure 2).

Distribution of histopatholgical changes with size of dental follicles of the complete impacted $3^{\text {rd }}$ molars: In the relationship of dental follicle size to dental follicle of the complete impacted $3^{\text {rd }}$ molars, the median size was $2.2 \mathrm{~mm}$ with S.D equal to $0.462 \mathrm{~mm}$, and the Mode was $3 \mathrm{~mm}$. Twelve $(86 \%)$ of histopatholgical changes were in dental follicles size of $0.5 \mathrm{~mm}-<2.5 \mathrm{~mm}$, and only two cases $(14 \%)$ were in dental follicle size $2.5 \mathrm{~mm}-\leq 3 \mathrm{~mm}$ and all these differences were significant $(p=0.008)$ (Table 1).

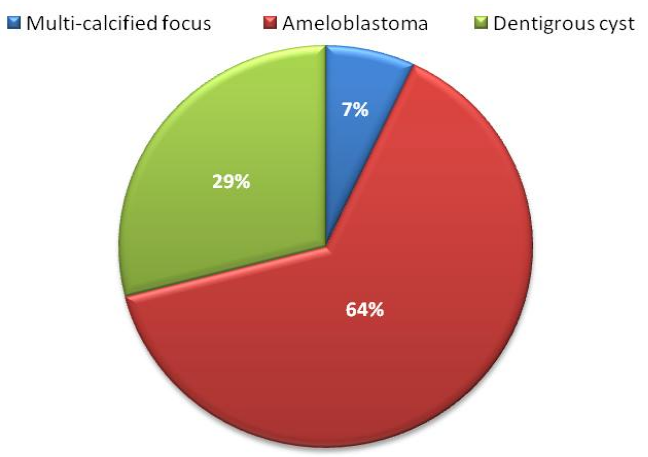

Figure 2: Types of histopathological changes in dental follicles of the complete impacted $3^{\text {rd }}$ molars.

Distribution of histopathological changes in dental follicles with site (MandiblelMaxilla) and side (rightlleft): Of the fifty dental follicles from complete impacted $3^{\text {rd }}$ molars, thirty are dental follicle from the mandible $(60 \%)$ and twenty dental follicles from the maxilla $(40 \%)$. Nine $(65 \%)$ were histopathological changes in the lower jaw - five cases were on the right (36\%) and four cases were on the left $(29 \%)$, while the upper jaw was five $(35 \%)$ - two cases $(14 \%)$ were on the right. And three cases (21\%) were on the left.

Table 1: The distribution of histopathological changes in dental follicles with size.

\begin{tabular}{llllll}
\hline Size & \multicolumn{2}{c}{$<\mathbf{5 m m}$} & \multicolumn{2}{c}{$\begin{array}{c}2.5 \mathrm{~mm}-\leq 3 \\
\mathbf{m m}\end{array}$} & $\mathrm{P}$ - value \\
\cline { 2 - 5 } & No. & $\%$ & No. & $\%$ & \\
\hline $\begin{array}{l}\text { Pathological } \\
\text { changes }\end{array}$ & 12 & 86 & 2 & 14 & 0.008 \\
\hline
\end{tabular}

Table 2: The distribution of histopathological changes in site (MandiblelMaxilla) and side (rightlleft).

\begin{tabular}{|c|c|c|c|c|c|c|c|c|}
\hline \multirow{5}{*}{ 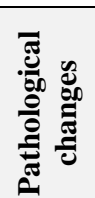 } & \multicolumn{3}{|c|}{ Mandible } & \multicolumn{2}{|c|}{ Maxilla } & \multicolumn{2}{|c|}{ Total } & \multirow{2}{*}{ P-value } \\
\hline & \multirow{4}{*}{$\begin{array}{l}\text { Right } \\
\text { Left }\end{array}$} & No. & $\%$ & No. & $\%$ & No. & $\%$ & \\
\hline & & 9 & 65 & 5 & 35 & 14 & 100 & 0.3 \\
\hline & & 5 & 36 & 2 & 14 & 7 & 50 & \\
\hline & & 4 & 29 & 3 & 21 & 7 & 50 & 1 \\
\hline
\end{tabular}




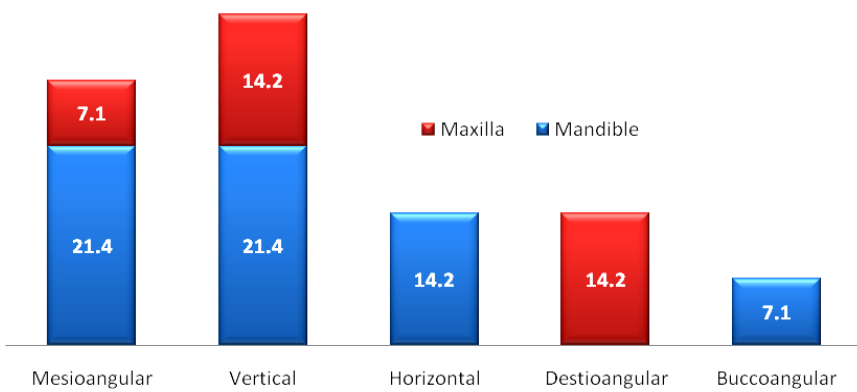

Figure 3: The distribution of histopathological changes and angulations of impacted $3^{\text {rd }}$ molars (Winter's classification) in both jaws.

There were no statistically significant differences for site and side $(p>0.05)$ (Table 2).

The distribution of histopatholgical changes and angulation (Winter's classification):

Five $(36 \%)$ of histopathological changes were vertically complete impacted $3^{\text {rd }}$ molars-three cases $(21.4 \%)$ in mandible and two cases $(14.2 \%)$ in maxilla. Four $(29 \%)$ were mesioangular -three cases $(21.4 \%)$ in mandible and only one case $(7.1 \%)$ in maxilla. While horizontal were two cases and buccoangular was only one case $(14.2 \%)$ and $(7.1 \%)$, respectively in mandible only. Destioangular were two cases (14.2\%) in maxilla (Figure 3).

Table 3: The distribution of histopathological changes in dental follicles of the complete impacted

\begin{tabular}{llll}
\multicolumn{3}{c}{$\mathbf{3}^{\text {rd }}$ molars with gender. } \\
\hline \multirow{3}{*}{ Hender } & $\begin{array}{l}\text { Histopathological } \\
\text { changes }\end{array}$ & \\
\cline { 2 - 4 } & Number & $\%$ & P-value \\
\hline Females & 12 & 86 & \\
Males & 2 & 12 & 0.008 \\
Total & 14 & 100 & \\
\hline
\end{tabular}

Distribution of histopathological changes of dental follicles with gender: A total of the fifty dental follicles of the complete impacted $3^{\text {rd }}$ molars were removed, twelve $(86 \%)$ of histopathological changes were in female and in male were only two (14\%), and there was statically significant differences $(p=0.008)$ (Table 3$)$.

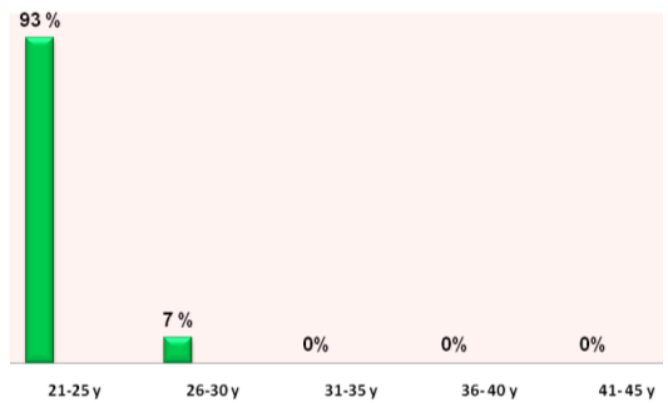

Figure 4: The distribution of histopathological changes in dental follicles with age groups.

Distribution of histopathological changes in dental follicles with age groups: Of the fifty dental follicles of the complete impacted $3^{\text {rd }}$ molars included in the study with mean age was (23 years old), thirteen
(93\%) of histpathological changes occurred in age group (21-25 years old), then only one case ( $7 \%$ ) in age group (26-30 years old ). While in other age groups none occurred (Figure 4).

Distribution of histopatholgical changes in the dental follicles with reasons of extractions: Eight cases $(57.1 \%)$ were extracted for orthodontic needs, followed by three cases that had anchorage loss (mesial collapse) (21.4\%), then two cases (14.3\%) had temporomandibular joint (T.M.J) pain, and only one case $(7.1 \%)$ for prophylactic (Figure 5 ).

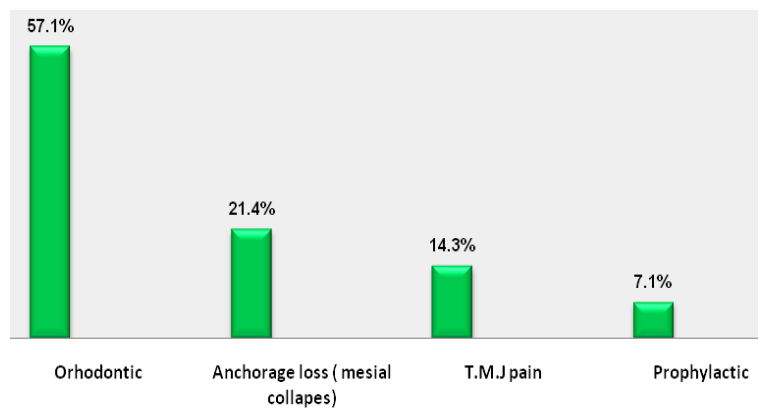

Figure 5: Distribution of histopathological changes in dental follicles with reasons of extractions.

\section{DISCUSSION}

In the present study, the incidence of histopatholgical changes in dental follicles of complete impacted $3^{\text {rd }}$ molars were fourteen cases $(28 \%)$ and thirty six cases $(72 \%)$ were reported with no histopathological changes and chronic non- specific inflammatory cells. Most of the histopathological changes were ameloblastoma like-lesion $(9 / 14 ; 64 \%)$, four were dentigerous cyst $(4 / 14 ; 28 \%)$, and only one case was multicalcified focus with islands of odontogenic epithelium $(1 / 14 ; 7 \%)$. The result of our study compared favorably that performed by Shaat ${ }^{14}$, who found that important pathological lesions were diagnosed in $(29 \%)$ of cases and $(71 \%)$ were normal follicles, but in his study $(57.7 \%)$ showed Dentigerous cyst. $(5 \%)$ ameloblastoma and only $(0.9 \%)$ were odontogenic keratocyst. Yildirm et al., ${ }^{15}$ also noted pathology changes $(23 \%)$ of their study group and the remaining specimens $(77 \%)$ were diagnosed as normal tissue. Of these pathological specimens $14.1 \%$ were dentigerous cysts, $6.6 \%$ were Calcifying Cystic Odontogenic cyst (CCOT) and $2.5 \%$ were Odontogenic Keratocyst (OKC). Also in the study of Haidry et al., ${ }^{16}$ found cystic changes in $(24 \%)$ of radiologically normal 
Lower impacted third molars (LITMs) and $76 \%$ were Dental Follicle (DF) normal. In further agreement is the work by Dongel et al., ${ }^{17}$ who in their study of 113 follicle tissue found $15.9 \%$ cystic changes and $84.1 \%$ no cystic changes. In a study by Adesperger et al., ${ }^{18}$ they found that $(34 \%)$ of dental follicles exhibited squamous metaplasia indicating cystic changes equivalent to those found in Dentigerous cysts. However; in a study by Vignewaran and Shilpa ${ }^{19}$ it was shown that $(61.4 \%)$ were cysts and tumors and $(38.6 \%)$ cases were normal with chronic inflammatory cells. In this study, twelve $(86 \%)$ tooth follicles in size (less than $2.5 \mathrm{~mm}$ ) had histological changes, while in follicle that measured $(2.5-3 \mathrm{~mm})$ only two $(14 \%)$ had HC. Similarly in a study by Tambuwala et $a l .,{ }^{20}$ they noted that the incidence of cystic changes was higher in follicle size between $(1-1.5 \mathrm{~mm})(33.3 \%$ and $66.7 \%$, respectively), and that follicles of $2 \mathrm{~mm}$ were had none. Furthermore, Dongol et al., ${ }^{17}$ observed cystic changes were more in follicle size of $0.5 \mathrm{~mm}(25 \%)$ and $20 \%$ were in size of $2.5 \mathrm{~mm}$, and Adelsperger et al., ${ }^{18}$ had shown that $32 \%$ of cystic changes were in DF size less than $2.5 \mathrm{~mm}$. With regard to site (mandiblelmaxilla) and side (rightlleft), the results in this study showed dental follicles of the complete impacted $3^{\text {rd }}$ molars were thirty dental follicles from mandible $(60 \%)$ and twenty from maxilla (40\%).Among this study, thirty one cases $(62 \%)$ in right-side, and nineteen $(38 \%)$ in left-side. Nine $(65 \%)$ of histopathological changes were in mandible $-5(36 \%)$ cases in right-side, and four cases in left-side $(29 \%)$, while in maxilla five cases $(35 \%)$-Two cases $(14 \%)$ in right-side and three cases $(21 \%)$ in left-side. Similar in a study done by Seyedmajidi et al., ${ }^{21}$ found that cystic changes were observed in $(55 \%)$ follicles of madndibular $3^{\text {rd }}$ molar, while $(28 \%)$ from maxilla and the incidence of pathological changes in mandible was 1.957 times more than maxilla. Study showed that the most histopathological changes were in mandible, that may be lower third molar is the last tooth erupted in oral cavity. With consideration to angulation according to Winter's classification, nineteen cases were $(38 \%)$ mesioangular, then fourteen cases $(28 \%)$ vertical, nine $(18 \%)$ were destioangular, seven (14\%) were horizontal, and only one case (2\%) was buccoangular. Most of changes in this study were in vertical and mesioangular angulation, five cases $(36 \%)$ and four cases $(29 \%)$, respectively. Followed by destioangular and horizontal two cases in each one (14.2\%) and only one case $(7.1 \%)$ was buccoangular. Similar study done by Șimșek-Kaya et al., ${ }^{22}$ showed that vertical and mesioangular inclined molars have greater tendency toward pathological changes. While in a study by Mehrotra and David ${ }^{23}$, found mesioangular impacted molars were associated with higher incidence of cystic changes. Tambuwala et al., ${ }^{20}$ reported that $20 \%$ mesioangular and $16.7 \%$ vertical impacted $3^{\text {rd }}$ molars were diagnosed as cystic follicle. The finding in this study which showed most of histopatholgical changes in vertical and mesioangular that may be related to failure of impacted third molars to rotate from mesioangular to vertical position, but causes are still unknown. With regard to the gender and distribution of histopathological changes. Fifty follicular tissues were obtained, and among them thirty eight females $(76 \%)$ and twelve $(24 \%)$ were males. Our result is in agreement with previous studies, Yildirim et al., ${ }^{15}$ and Simsek-Kaya et al., ${ }^{22}$ who notated that pathological changes were more in female than the male. On the other hand Kotrashetti et al., ${ }^{24}$ found that the pathological changes in follicles were more in males as compared to females, (90\%) males and (47.6\%) females. The findings of this study, females were more than males were attributed to the size of female jaw. In the current study; of the total fifty dental follicles of the complete impacted $3^{\text {rd }}$ molars, thirty nine $(76 \%)$ were within age group $(21-25 y)$, then age group (26-30y) and (31-35y) were four $(8 \%)$ to each one, two cases $(4 \%)$ in age group (36-40y), and only one $(2 \%)$ in age group (41-45y). Among them, thirteen $(93 \%)$ of histopathological changes were in age group $(21-25 \mathrm{y})$. This result is similar to study by Vignesaaran and Shilpa ${ }^{19}$ where they found that peak incidence of pathologies occurred between the age group $(20-30 \mathrm{yr})$. With regard to the reasons of extraction, we found twenty one $(42 \%)$ due to orthodontic treatment, twelve $(24 \%)$ due to pain in T.M.J., nine (18\%) due to anchorage loss (mesial collapse), and eight (16\%) for prophylactic. Among this study histopathological changes were found in eight orthodontic patients $(57.1 \%)$, then three cases $(21.4 \%)$ and two cases $(14.3 \%)$ in patients who had anchorage loss (mesial collapse) and T.M.J pain, respectively, and only one case $(7.1 \%)$ for prophylaxis. Shaat $^{14}$, reported that the reasons for removal were orthodontic treatment, pain and destruction of adjacent tooth, while Naves et al., ${ }^{25}$, and Palma et al., ${ }^{26}$ identified the most common reasons to be for orthodontic treatment. Meanwhile, Dongel et al., ${ }^{17}$ in their study the most common cause of extraction of the impacted mandibular third molars was recurrent pericoronitis $(84.1 \%)$, followed by carious second molar $(6.2 \%)$ and prophylaxis $(3.5 \%)$. Whereas Kotrashetti et al., ${ }^{24}$ for prophylaxis and orthodontic needs (before treatment, after treatment and during the course of orthodontic treatment).

\section{CONCLUSION}

In conclusion, a high incidence of $\mathrm{HC}$ occurred in patients with DF, and it was associated with smaller dental follicle size, most $\mathrm{HC}$ was ameloblastoma, followed by dentigerous cyst, while $72 \%$ of samples had normal follicles and non-specific chronic inflammatory cells. There is a correlation between female gender, younger age group, and jaw position with HC. Prophylactic extraction of the asymptomatic impacted third molar should be routinely practiced in Yemen, to reduce the risk of pathological changes, especially in females and younger age groups.

\section{AUTHOR'S CONTRIBUTION}

This study was carried out by Shafiqa Mohammed Haidra Masdoose for Oral and Maxillofacial Surgery MSc degree under the supervision of Assisstant 
Professor Dr. Akram Thabet Nasher, Oral and MAxillofacial Surgery department, Faculty of Dentistry, Sana'a University.

\section{ACKNOWLEDGEMENTS}

The authors would like to acknowledge Sana'a University, Sana'a, Yemen which supported this work.

\section{CONFLICT OF INTEREST}

No conflict of interest associated with this work.

\section{REFERENCES}

1. Villalba L, Stolbizer F, Blasco F, Mauriño N, Piloni M, Keszler A. Pericoronal follicles of asymptomatic impacted teeth: a radiographic, histomorphologic, and immunohistochemical study. Int J Dent 2012;1-6. https://doi.org/10.1155/2012/935310

2. Satheesan E, Tamgadge S, Tamgadge A, Bhalerao S, Periera T. Histopathological and radiographic analysis of dental follicle of impacted teeth using modified Gallego's stain. J Clin Diagn Res 2016; 10(5):ZC106-ZC111. https://doi.org/10.7860/JCDR/2016/16707.7838

3. Levey RJ. A modified Gallego's iron fuschin stain as a differential stain for cementum. J Dent Res 1956 Jun; 35(3):491-3.https://doi.org/10.1177/00220345560350032101

4. Abbas AM, Al-Kibsi TAM, Al-Akwa AAY, et al. Characterization and antibiotic sensitivity of bacteria in orofacial abscesses of odontogenic origin. Universal J Pharm Re 2020; 5(6):55-61. https://doi.org/10.22270/ujpr.v5i5.478

5. Al-Kebsi AM, Othman AM, Hassan A. Al-Shamahy, et al. Oral C. albicans colonization and non-candida albicans candida colonization among university students, Yemen. Universal J Pharm Res 2017; 2(5): 5-10. https://doi.org/10.22270/ujpr.v2i5.R2

6. Al-deen AAS, Al-deen HMS, Abbas AKM, et al. Knowledge and perception of molar incisor hypomineralization among dental practitioners in Sana'a city-Yemen. Universal J Pharm Res 2020; 5(5):4-11. https://doi.org/10.22270/ujpr.v5i5.479

7. AL-Awadi TAM, AL-Haddad KA, Al-labani MA, AlShamahy HA. Prevalence of malocclusion among Yemeni children of primary schools. Universal J Pharm Res 2019; 5(1): 1-6. https://doi.org/10.22270/ujpr.v5i1.329

8. Ulrahman MAASA, Yahya A, Al-Shamahy HA, Abbas AKMA. Occurrence of retromolar canal among a sample of Yemeni adults obtained from cone-beam computed tomography. Int Res J Med Med Sci 2020; 8(2): 35-41.

9. Alhadi Y, Rassem AH, Al-Shamahy HA, Al-Ghaffari KM. Causes for extraction of permanent teeth in general dental practices in Yemen. Universal J Pharm Res 2019; 4(2): 1-5. https://doi.org/10.22270/ujpr.v4i2.231

10. Mutaher NJA, AL-Haddad KA, Al-Akwa AAY, Al-labani MA, Al-Shamahy HA, Zabara AQMQ, Al-deen HMS. Prevalence and causes of traumatic dental injuries to anterior teeth among primary school children in Sana'a city, Yemen. Universal J Pharm Res 2020; 5(3):38-43. https://doi.org/10.22270/ujpr.v5i3.329

11. Al-Sharani AA, Al-Hajj W, Al-Shamahy HA, Jaadan BM. The effect of nanosilver and chlorhexidine mouthwash on anaerobic periodontal pathogens counts. Universal J Pharm Res 2019; 4(5): 1-6. https://doi.org/10.22270/ujpr.v4i5.309
12. Al-Shamahi NYA, Abbas Al-Kasem M, Al-Shamahy HA, et al. Radiographic assessment of the course and visibility of the mandibular canal by panoramic radiography. Universal $\mathbf{J}$ Pharm Res 2020; 5(5): 17-20. https://doi.org/10.22270/ujpr.v5i5.481

13. Al-Shamahy HA, Abbas AMA, Mahdie Mohammed AM, Alsameai AM. Bacterial and Fungal Oral Infections Among Patients Attending Dental Clinics in Sana'a City-Yemen. On J Dent Oral Health 2018; 1(1). https://doi.org/10.33552/OJDOH.2018.01.000504

14. Shaat G. Histological and radiographic study of pathologic changes in fully impacted lower third molars dental follicles. Damascus University. M.Sc. 2009. https://doi.org/10.7860\%2FJCDR\%2F2016\%2F16707.7838

15. Yildirim G, Ataoğlu H, Mihmanli A, Kiziloğlu D, Avunduk MC. Pathologic changes in soft tissues associated with asymptomatic impacted third molars. Oral Surg Oral Med Oral Pathol Oral Radiol Endod 2008; 106(1):14-8. https://doi.org/10.1016/j.tripleo.2007.11.021

16. Haidry N, Singh M, Mamatha NS, Shivhare P, Girish HC, Ranganatha N, Kashyap S. Histopathological evaluation of dental follicle associated with radiographically normal impacted mandibular third molars. Ann Maxillofac Surg 2018; 8(2):259-264 https://doi.org/10.4103/ams.ams_215_18

17. Dongol A, Sagtani A, Jaisani MR, et al. Dentigerous cystic changes in the follicles associated with radiographically normal impacted mandibular third molars. Int J Dent 2018; 20(26):2-5. https://doi.org/10.1155/2018/2645878

18. Adelsperger J, Campbell JH, Coates DB, Summerlin DJ, Tomich CE. Early soft tissue pathosis associated with impacted third molars without pericoronal radiolucency. Oral Surg Oral Med Oral Pathol Oral Radiol Endod 2000; 89(4):402-6. https://doi.org/10.1016/s1079-2104(00)70119-3

19. Vigneswaran AT, Shilpa S. The incidence of cysts and tumors associated with impacted third molars. J Pharm Bioallied Sci 2015;7(Suppl 1):S251-4. https://doi.org/10.4103/0975-7406.155940

20. Tambuwala AA, Oswal RG, Desale RS, Oswal NP, Mall PE, Sayed AR, Pujari AT. An evaluation of pathologic changes in the follicle of impacted mandibular third molars. J Int Oral Health 2015;7(4):58-62. PMID: 25954073

21. Seyedmajidi SK, Haghanifar S, Mehdizadeh M, Seyedmajidi $\mathrm{M}$, Bijani A, et al. Evaluation of panoramic radiography at showing width of the dental follicle. Zahedan J Res Med Sci 2014; 16(7):35-39.

22. Simşek-Kaya G, Özbek E, Kalkan Y, Yapici G, Dayi E, Demirci T. Soft tissue pathosis associated with asymptomatic impacted lower third molars. Med Oral Patol Oral Cir Bucal 2011; 16(7):e929-36. https://doi.org/10.4317/medoral.17128

23. Mehrotra V, David M. Pathologic changes in dental follicle associated with third impactions- a study. Pakistan Oral Dent J 2010; 30(2):330-334.

24. Kotrashetti VS, Kale AD, Bhalaerao SS, Hallikeremath SR Histopathologic changes in soft tissue associated with radiographically normal impacted third molars. Indian J Dent Res 2010; 21(3):385-90. https://doi.org/10.4103/0970-9290.70809

25. Naves MD, Sette-Dias AC, Neves Abdo E, Gome RS. The histopathological examination of the dental follicle of asymptomatic impacted tooth: is it necessary? Arch Oral Res 2012; 8 (1):67-71

26. de Mello Palma V, Danesi CC, Arend CF, Venturini AB, Blaya DS, Neto MM, et al. Study of pathological changes in the dental follicle of disease-free impacted third molars. J Maxillofac Oral Surg 2018; 17(4):611-615. https://doi.org/10.1007/s12663-018-1131-2 